\title{
PENGARUH MODEL PEMBELAJARAN RCCDE TERHADAP KETERAMPILAN KOLABORASI SISWAPADA MATERI PENCEMARAN LINGKUNGAN
}

\author{
${ }^{1}$ Bella Islami Lestari, ${ }^{2}$ Siti Roudlotul Hikamah, ${ }^{3}$ Imam Bukhori Muslim \\ ${ }^{123}$ Pendidikan Biologi, Universitas Islam Jember \\ 1bellaislami497@gmail.com,2sitihikamah@yahoo.com,3imambukhori916@yahoo.com
}

\begin{abstract}
ABSTRAK
Dalam penelitian ini bertujuan untuk mengetahui Pengaruh Model Pembelajaran RCCDE terhadap Keterampilan Kolaborasi Siswa pada Materi Pencemaran Lingkungan Kelas VII di SMP PGRI Mumbulsari.Tujuan khusus penelitian ini menguji signifikansi keterampilan kolaborasi siswa. Design penelitian ini dipilih secara acak, pada kelas A tersebut melaksanakan pembelajaran RCCDE yang telah dikembangkan sebagai kelas eksperimen, sedangkan pada kelas B menggunakan model pembelajaran konvensional sebagai kelas kontrol. Metode pengumpulan data menggunakan teknik tes dan teknik observasi. Metode analisis data menggunakan uji persyaratan analisis Kruskal Wallis yang dioperasikan menggunakan SPSS. Berdasarkan hasil penelitian dalam pengambilan keputusan uji Statistik non parametrik yaitu Jika nilai Asymp.Sig $<0,05$ maka ada pengaruh atau $\mathrm{H} 0$ ditolak dan Ha diterima. Jika nilai Asymp.Sig > 0,05 maka tidak ada pengaruhatau H0 diterima dan Ha ditolak. Diketahui bahwa nilai Asymp.Sig sebesar 0,000 maka dapat disimpulkan H0 ditolak dan Ha diterima yang artinya ada pengaruh yang signifikan antara Kelas Kontrol dan kelas Eksperimen. Hal tersebut dapat disimpulkan bahwa ada pengaruh yang signifikan.
\end{abstract}

Kata Kunci : Model RCCDE, Keterampilan Kolaborasi, Pencemaran Lingkungan

\section{ABSTRACT}

In this study, the aim of this study was to determine the effect of the RCCDE Learning Model on Student Collaboration Skills in Class VII Environmental Pollution Material at SMP PGRI Mumbulsari. The specific objective of this study was to test the significance of students' collaboration skills. The research design was chosen randomly, in class A the RCCDE learning was implemented as an experimental class, while in class B used the conventional learning model as the control class. Methods of data collection using test techniques and observation techniques. The data analysis method used the Kruskal Wallis analysis requirements test which was operated using SPSS. Based on the results of research in the non-parametric statistical test decision making, namely if the Asymp.Sig value $<0.05$ then there is an influence or $\mathrm{HO}$ is rejected and Ha is accepted. If the Asymp.Sig value $>0.05$ then there is no effect or HO is accepted and Ha is rejected. It is known that the Asymp. Sig of 0.000, it can be concluded that it can be concluded that $\mathrm{HO}$ is rejected and $\mathrm{Ha}$ is accepted, which means that there is a significant influence between the Control Class and the Experiment Class. It can be concluded that there is a significant effect.

Kata Kunci : RCCDE Model, Collaboration Skills, Environmental Pollution

\section{PENDAHULUAN}

Proses pembelajaran di dalam kelas merupakan suatu dunia komunikasi tersendiri yang di dalamnya terjadi pertukaran pikiran antara guru dan siswa untuk mengembangkan suatu ide. Pembelajaran juga merupakan kegiatan manusia yang kompleks, yang tidak sepenuhnya dapat dijelaskan. Pembelajaran secara sempit dapat diartikan sebagai produk interaksi berkelanjutan antara pengembangan dan pengalaman hidup.

Berdasarkan hasil observasi penulis di SMP PGRI Mumbulsari pada tanggal 20 November 2019, menginformasikan bahwa proses pembelajaran dilakukan dengan metode ceramah sehingga siswa kurang aktif. Secara umum, ketika proses pembelajaran berlangsung di dalam kelas, siswa hanya menjawab 
pertanyaan jika diajukan oleh guru. Selain itu, siswa terlihat kurang termotivasi untuk mengikuti proses pembelajaran. Hal ini dapat dilihat dari tidak ada kemauan dari para siswa untuk bertanya kepada guru ketika guru memberikan waktu untuk bertanya.

Di abad-21 ini kita ditantang untuk mampu menciptakan tata pendidikan yang dapat menghasilkan sumber daya pemikir yang mampu membangun tatanan sosial dan ekonomi sadar pengetahuan sebagaimana layaknya warga dunia di abad-21. Tentu saja dalam memandang ke depan dan merancang langkah kita tidak boleh sama sekali berpaling dari kenyataan yang mengikat kita dengan realita kehidupan (BSNP, 2010).

Reading merupakan proses pemahaman atau penikmatan terhadap teks bacaan yang melibatkan proses berfikir, bernalar dan mengolah informasi, maupun mengamati tulisan secara visual dengan memanfaatkan kemampuan melihat (mata) untuk tujuan memperoleh informasi (Susilo, 2015). Untuk membuat peta konsep, peserta didik dilatih untuk mengidentifikasi ide - ide kunci yang berhubungan dengan suatu topic dan menyusun ide - ide tersebut dalam suatu pola logis (Parlin, 2013). Connection adalah keselarasan antara fakta atau bisa dikatakan dengan mengaitkan sebuah konsep dengan kenyataannya, yaitu bisa berupa praktikum, studi lapanga, melalui media visual yaitu video dan lain lain. Di dalam diskusi ini proses interaksi antara dua atau lebih individu yang terlibat, saling tukar menukar pengalaman, informasi, memecahkan maslah, dapat terjadi juga semuanya aktif tidak ada yang pasif sebagai pendengar saja (Roestiyah, 2008). Evaluation adalah suatu kegiatan yang disengaja dan bertujuan.

Menurut Bluemel dan Taylor
(2012) Pop-Up Book adalah sebuah buku yang menampilkan potensi untuk bergerak dan interaksinya melalui penggunaan kertas sebagai bahan lipatan, gulungan, bentuk, roda, atau putarannya.

Keterampilan kolaborasi adalah kemampuan berpartisipasi dalam setiap kegiatan untuk membina hubungan dengan orang lain, saling menghargai hubungan dan kerja tim untuk mencapai tujuan yang sama (Le, Janssen \& Wubbles, 2017). Kemampuan dalam hal berinteraksi dengan menghargai perbedaan, berpartisipasi dalam diskusi, sumbang saran, mendengarkan, dan mendukung orang lain (Sari, Prasetyo, \& Setiyo, 2017).

Berdasarkan permasalahan diatas, maka peneliti telah melakukan penelitian mengenai penerapan model pembelajaran RCCDE untuk meningkatkan hasil belajar siswa. Penelitian ini diberi judul: pengaruh model pembelajaran RCCDE terhadap keterampilan kolaborasi siswa pada materi pencemaran lingkungan.

\section{METODE PENELITIAN}

Rancangan Penelitian ini merupakan penelitian kuantitatif dengan jenis penelitian kuasi eksperimen Nonequivalent control group design. Design penelitian ini dipilih secara acak, dan terpilih kelas A dan Kelas B. Pada kelas A tersebut melaksanakaan pembelajaran RCCDE yang telah dikembangkan sebagai kelas eksperimen, sedangkan pada kelas B menggunakan model pembelajaran konvensional sebagai kelas kontrol.

Variabel Penelitian ini menggunakan 2 variabel, yaitu variabel bebas dan variabel terikat. Variabel bebas yaitu variabel yang mempengaruhi atau disebut $X$ dalam penelitian ini variabel bebasnya yaitu "Penggunaan model RCCDE (Reading Concept Map 
Connection Discussion Evalution). Variabel terikat yaitu variabel yang mempengaruhi atau yang disebut variabel Y dalam hal ini variabel terikat adalah keterampilan kolaborasi dan hasil belajar siswa.

Populasi dari penelitian ini adalah siswa SMP PGRI Mumbulsari pada semester genap tahun ajaran 2019/2020. Kelas VII terdapat beberapa kelas peneliti membagi dengan cara mengundi dan terpilih dua kelas yaitu kelas VII ${ }^{\mathrm{A}}$ dan kelas VII ${ }^{\mathrm{B}}$, untuk Kelas $\mathrm{VII}^{\mathrm{A}}$ sebagai kelompok eksperimen dan kelas VII $^{\mathrm{B}}$ sebagai kelas kontrol.

Metode pengumpulan data pada penelitian ini adalah data keterampilan kolaborasi siswa, untuk itu dalam penelitian ini akan menggunakan teknik tes dan observasi. Tes ini bertujuan untuk mengetahui pengaruh yang terjadi pada keterampilan proses dan hasil belajar IPA siswa setelah adanya perlakuan pada kelompok kelas. Teknik observasi yang digunakan adalah menggunakan instrument lembar observasi keterampilan proses IPA.

a. Metode Analisis Data

a. Tahap Rencana

1) Penyusunan RPP

2) Pembuatan Media Pop UpBook

3) Pembuatan Soal

4) Pembuatan Angket Keterampilan Kolaborasi

5) Penentuan Jadwal Penelitian

6) Tindakan

b. Uji Hipotesis

Pada penelitian ini menggunakan uji Normalitas dan uji statistic non parametrik untuk mengetahui keterampilan kolaborasi siswa yang diberi model pembelajaran RCCDE dengan model konvensional. Untuk menguji hipotesis ini menggunakan SPSS versi 20.0

\section{HASIL DAN PEMBAHASAN}

Berdasarkan hasil penelitian yang dilakukan oleh peneliti dengan menggunakan angket untuk mengetahui keterampilan kolaborasi siswa. Hasil pengamatan angket keterampilan kolaborasi pada kelas kontrol dengan nilai rata - rata 31,6 sedangkan pada kelas eksperimen dengan rata - rata 34. Adapun grafik hasil keterampilan kolaborasi siswa pada kelas kontrol dan kelas eksperimen adalah sebagai berikut :

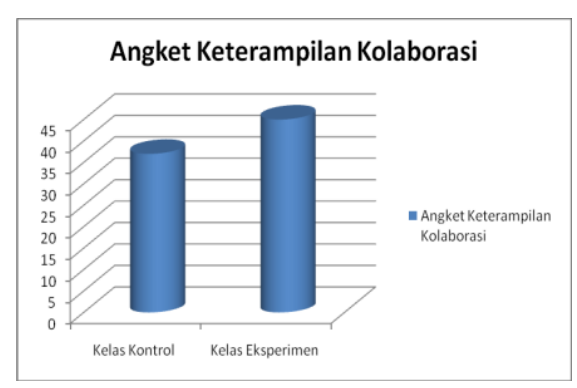

Sumber : data diolah

Gambar. Perbandingan keterampilan kolaborasi siswa pada kelas kontrol dan kelas eksperimen

Berdasarkan hasil grafik tersebut bahwasannya ada pengaruh antara kelas kontrol mapun kelas eksperimen dan pada hasil analisis statistik menunjukkan bahwa ada pengaruh yang signifikansi. Berdasarkan hasil analisis deskripsi, maka dapat disimpulkan bahwa dari penggunaan model pembelajaran RCCDE ini baik kelas kontrol maupun kelas eksperimen sama - sama ditekankan untuk memiliki keterampilan kolaborasi dalam pembelajaran IPA. Karena guru pada penggunaan model RCCDE dapat mengajarkan siswa keterampilan - keterampilan kognitif penting dengan menciptakan pengalaman belajar, dan kemudian membantu siswa mengembangkan 
keterampilan tersebut atas usaha yang dimiliki mereka sendiri dengan pemberian semangat. Sehingga siswa dapat mempelajari beberapa strategi pemahaman mandiri secara spesifik yaitu reading, consept map,connection, discussion, dan evaluasion. Adapun siswa yang kurang memahami bagaimana cara membuat peta konsep dan berdiskusi karena pada dasarnya siswa lebih terbiasa dengan metode ceramah. Siswa yang terbiasa menerima informasi dari guru melalui ceramah, sehingga siswa tidak terbiasa menelaah informasi melalui membca dan membuat peta konsep serta berdiskusi.

Penggunaan model pembelajaran RCCDE memiliki beberapa kelebihan yang didapat oleh siswa sehingga dapat berpengaruh terhadap keterampilan kolaborasi dan hasil belajar siswa pada materi pencemaran lingkungan, yaitu sebagai berikut :

a. Reading adalah sebuah komponen dasar yang seseorang bisa memiliki pengetahuan yang lebih, dengan membaca siswa akan memiliki tingkat pengetahuan yang lebih dari dengan siswa yang tidak membaca buku (Arifatus, 2019).

b. Siswa dengan membaca buku materi dapat difahami dengan sempurna sehingga pemahaman dapat tertuang ke dalam map mapping atau peta konsep.

c. Setelah siswa membaca dilanjutkan dengan membuat peta konsep sesuai dengan kreatifitas yang dimiliki oleh masing masing siswa dengan suatu embe tertentu yang dihubungkan satu sama lain.

d. Siswa jadi lebih aktif dan berfikir dengan baik setelah membaca membuat peta konsep kemudian dengan adanya tampilan sebuah video siswa dapat berpendapat sesuai dengan apayang mereka fahami (Fiskabita, 2019).

e. Dengan adanya media pop-up book siswa lebih mudah mengingat materi yang disampaikan dengan menyalurkan pemikiran antar siswa tersebut.

f. Dalam penggunaan media PopUp Book menurut Dzuanda (2011) dapat menjadi daya tarik pembaca dan dapat mengajak interaktifitas pengguna baik secara pribadi maupun berkelompok.

g. Dilanjut dengan diskusi untuk menyalurkan pemikiran antar siswa agar lebih giat untuk saling berpendapat maupun bertukar pemikiran, sehingga mampu menghargai pendapat orang lain serta mampu mengemukakan hasil diskusinya antar temannya yang kemudian memberi evaluasi untuk memperbaiki hasil kedepannya.

\section{KESIMPULAN}

1. Model pembelajaran RCCDE dengan menggunakan pop up book sebagai media pembelajaran dapat meningkatkan keterampilan kolaborasi dengan diperoleh rata - rata sebesar 31,6 pada kelas kontrol sedangkan kelas eksperimen dengan rata - rata sebesar 34.

2. Model pembelajaran RCCDE dengan media pop up book dapat menjadi keterampilan kolaborasi bagi siswa sehingga siswa akan lebih aktif lagi, terhibur dan tertantang, serta siswa mempunyai rasa ingin tau terhadap apa yang akan dipelajarinya. 


\section{SARAN}

Berdasarkan hasil penelitian, maka saran yang dapat disampaikan adalah sebagai berikut :

1. Guru harus mampu menerapkan model pembelajaran RCCDE dengan media pop up book, agar kreatifitas siswa terus meningkat.

2. Dalam pembelajaran IPA disekolah, guru hendaknya menggunakan model pembelajaran RCCDE dengan media pop up book agar siswa lebih aktif lagi dalam memecahkan suatu masalah serta siswa juga bisa saling berkolaborasi.

\section{DAFTAR PUSTAKA}

Arifatus. 2019. Pengaruh Model Reading Concept Connection Discussion Evaluation (RCCDE) Terhadap Berfikir Kritis pada Materi Pencemaran Air. Jember. Universitas islam Jember.

Blumel \& Taylor. 2012. Pop-up Books A Guide For Teachers and Librarians. California: ABCCLJO, LLC.

Dzuanda. 2011. Design Pop-up Child Book Puppet Figures Series? Gatotkaca?. Jurnal Library ITS Undergraduate, (Online), (http:/ /library.its. Undergraduate.ac.id). Diakses 8 Desember 2019

Fiskabita. 2019. Pengaruh Model Pembelajaran RCCDE Terhadap Hasil Belajar Siswa di Kelas VIII MTs Nurul Ali pada Sistem Eksresi manusia. Jember. Universitas Islam Jember

Le, H., Jeroan, J., dan Theo.,W. (2017). Collaborative Learning Practices: teacher and student perceived obstacles to effective student collaborative.

Cambridge Journal of

Education,48(1), 110.

Parlin. 2013. "Peningkatan Hasil Belajar Sosiologi Melalui Penerapan Strategi Pengorganisasian Peta Konsep (Consept Mapping)." Jurnal Teknologi Pendidikan, Vol.6, No. 1 (1) : 1979-6692

Roestiyah. 2008. Strategi Belajar Mengajar. Jakarta: Rineka Cipta

Sadiman, Arif S. 2010. Media Pendidkan: Pengertian, pengembangan dan pemanfaatannya. Jakarta: PT Raja Grafindo Perkasa.

Sari, Prasetyo, \& Setiyo. 2017 Mendesain Model Pembelajaran Inovatif Progesif, Konsep Landasan dan Implemetasinya Pada KTSP. Kencan Prenada Media, Jakarta.

Susilo, Sigir Vebrianto. 2015. Cooperative Learning Make A Match Dalam Pembelajaran Reading Comprehension Di kelas IV Sekolah Dasar Jurnal Cakrawala Pendas, Volume I, No. 1 